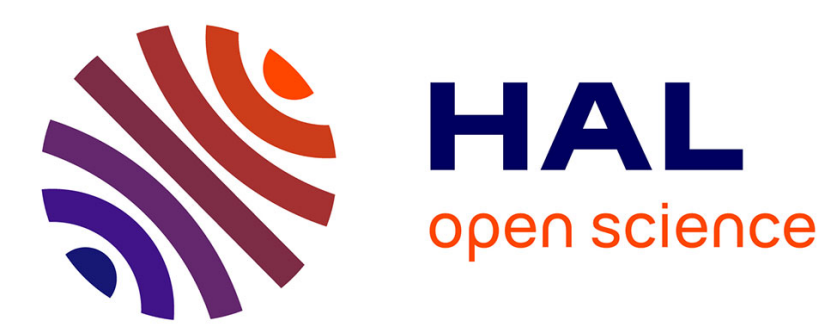

\title{
The Role of Migration Policy Changes in Europe for Return Migration to Senegal
}

\author{
Marie-Laurence Flahaux
}

\section{To cite this version:}

Marie-Laurence Flahaux. The Role of Migration Policy Changes in Europe for Return Migration to Senegal. International Migration Review, 2017, 51 (4), pp.868-892. 10.1111/imre.12248 . hal$01769021 \mathrm{v} 2$

\section{HAL Id: hal-01769021 \\ https://hal.science/hal-01769021v2}

Submitted on 21 Apr 2021

HAL is a multi-disciplinary open access archive for the deposit and dissemination of scientific research documents, whether they are published or not. The documents may come from teaching and research institutions in France or abroad, or from public or private research centers.
L'archive ouverte pluridisciplinaire HAL, est destinée au dépôt et à la diffusion de documents scientifiques de niveau recherche, publiés ou non, émanant des établissements d'enseignement et de recherche français ou étrangers, des laboratoires publics ou privés. 
The role of migration policy changes in Europe for return migration to Senegal

\author{
Marie-Laurence Flahaux
}

FLAHAUX, M.-L. (2017), "The role of migration policy changes in Europe for return migration to Senegal“, International Migration Review, 51 (4), 868-892, DOI: doi:10.1111/imre.12248.

\begin{abstract}
This paper questions the role of migration policy changes in France, Italy and Spain for return migration to Senegal, by analysing biographical data from the Migration between Africa and Europe survey (MAFE-Senegal) and the contextual data of the DEMIG VISA and DEMIG POLICY databases which cover major changes in migration policies in these destination countries for the different categories of migrants. Event history logistic regressions reveal that Senegalese migrants are less likely to return when the entry restrictions have become tighter. This result suggests that the decision to return depends on the possibility of migrating again after the return, which is crucial for both theory and policy regarding Western democracies' attempts to regulate migration.
\end{abstract}


In Europe, African migrants are often perceived as people fleeing wars and misery, and believed to remain permanently in their destination countries (de Haas 2005; Lessault and Beauchemin 2009). Therefore, according to public discourse, these migrants will generally not return to their origin countries unless they are encouraged or forced to do so. Return migration has generated increasing policy attention over the past decade, and for policy makers concerned with the management of international migration it has become a priority (Cassarino 2008). In particular, the European Union has implemented return support mechanisms targeting migrants from Africa, which was identified as "the first geographic priority" (Flahaux and Kabbanji 2013). The European Commission, through its Global Approach to Migration, encourages the return of migrants who are able to contribute to the development of their origin country, but strongly recommends the return of irregular migrants (Sinatti 2014). For this purpose, European governments have increasingly signed readmission agreements, implemented removals, and developed 'voluntary' return programmes.

At the same time, European countries have also implemented migration policies to control the access and stay of migrants from 'third countries'. These policies are generally assumed to have become more restrictive over time, although research has shown that this depends on the destination country and the migrant category (Geddes 2003). These entry restrictions may also have an effect on the circulation of migrants between their origin and destination countries.

The impact of different policies on return migration remains poorly understood due to the lack of individual data to study return migration and data assessing the changes in migration policies. This paper aims to fill this gap by focusing on Senegalese migrants in France, Italy and Spain, and using the transnational and biographical data from the Migration between Africa and Europe (MAFE) survey as well as the DEMIG policy and travel visa databases. These datasets enable us to analyse the effectiveness of different types of migration policies, namely those implemented to control the access of migrants to the destination country, those affecting their integration, and those aiming at encouraging or compelling their return. In addition, alterations in restrictiveness over time, differences between destination countries and between categories of migrants (irregular, high-skilled, low-skilled, asylum seekers and students) are taken into account.

The first section reviews the literature on the evolution of Senegalese migration and on the influence of migration policies on return migration. The second section presents the datasets used and the methods employed. The third section provides descriptive analyses of the sample of migrants and return migrants and demonstrates the evolution of the level of migration policy changes. It is followed by the results in the fourth section on the influence of migration policies on return migration to Senegal.

\section{General background and main hypotheses}

\subsection{History of Senegalese migration}

After independence in 1960, international migration from Senegal was mainly directed to West African countries and to France. Countries such as the Ivory Coast and Ghana offered opportunities to work in cocoa and coffee cultivation, and the previous colonial state France offered work in its developing automobile industry (Pison et al. 1997; Robin 1996). At that 
time, the Senegalese presence in France mainly comprised men coming from the region of the Senegal River Valley, who worked in industry and had left their families behind in their villages (Guilmoto 1998; Timera 1996). This migration was decided by the village elders, was temporary, and took place in the context of deteriorating living conditions in rural areas which were experiencing severe drought (Quiminal, 1991). Many migrants returned to their country of origin and were replaced by younger people from the same community (a system known as the "noria") (Barou 2001).

In 1974, a time of economic crisis, European states implemented migration restrictions. These restrictions ended the system of recruitment of foreign workers, thus effectively ending replacement migration (Barou 2001). Migrants had to choose between staying longer in France and returning to live permanently in Senegal. Some of them chose to bring their spouse(s) and children to Europe. This progressive transformation from a circulation to a settlement system has been described by previous research in other contexts, such as the case of Mexican migration to the United States (Massey et al. 2002; Massey and Pren 2012).

During the 1990s, Senegalese increasingly migrated to new destinations in Europe (Ma Mung 1996), with Italy and Spain emerging as new destinations (Robin 1996). Migration to Italy intensified after the introduction of a travel visa requirement in France in 1987 and a policy of regularisation in Italy in 1986. Initially, Senegalese migration to Italy took place as a secondary movement from France, where migrants found it increasingly difficult to gain and maintain secure legal status (Kaag 2008). When Italian visas became obligatory in 1991, however, these movements rapidly decreased (Bredeloup 1995). Senegalese traders also migrated to the United States (Dia 2009) and Spain attracted more and more migrants, given the opportunities it offered in agriculture and its informal labour market, even if their legal status and employment remained precarious (Suarez Navaz 1995). Years of migration restrictions have demonstrated growing irregular migration among Senegalese in Europe, but variation in policies in the different destination countries have created different pathways of irregularity (Vickstrom 2014). The changing composition of the migrant stream is similar to the case of Mexican migration in the United States, as demonstrated by Garip (2012).

The qualitative literature, that mainly focuses on the Senegalese presence in Italy and Spain, highlights the importance of the links new generations of Senegalese migrants continue to have with their origin country. The migrants' objective is to improve their socioeconomic situation and that of their family. During their migration they save money to invest in income-generating activities in Senegal. Owning a house or business in Senegal is therefore a prerequisite for their return. For Senegalese, successful migration is associated with an improvement in living conditions and a definitive return to Senegal (Sinatti 2011). Many of them distinguish themselves from other groups of migrants who left their country of origin to settle permanently in Europe (Hernandez Carretero 2012). As Castagnone et al. (2005) assert, in Senegal, migration is seen as a heroic act and return as a key objective. Described as "transmigrants", they invest emotionally in Senegal and are oriented towards a future return (Riccio 2006). Although return is central to the migration projects of many Senegalese, they often encounter difficulties during their migration, arising from the fact that they have a hard time building up financial reserves and because they are expected to share their savings with their family in Senegal. This explains why they often have to postpone their return to a later date than anticipated (Hernandez Carretero 2012). Nevertheless, this qualitative literature on the question of return for Senegalese migrants has not addressed the role of migration policies for return. 


\subsection{The role of migration policies}

The theories of neoclassical economics and new economics of labour migration (NELM) are at work in the case of Senegalese migration and suggest different pathways through which the policy environment plays a part in the eventual return of Senegalese migrants. The neoclassical theory considers migration as permanent due to the wages differential between Senegal and Europe (Todaro 1969). Return is therefore understood as the consequence of a failure abroad (de Haas and Fokkema 2011), and may result from policies hampering the integration of migrants or forcing them to return. The NELM, in contrast, considers that migrants will return once they have acquired the resources needed to overcome market imperfections and are able to improve the living conditions of their household in the origin country (de Haas and Fokkema 2011). This theory seems to be in line with previous research on Senegal (see above). Due to restrictive migration polities affecting the integration of migrants in the destination countries, migrants may postpone their return because it may take longer than anticipated for migrants to acquire the resources needed. This theory could suggest the policies regulating the entry of migrants to their territory could also affect their return, as migrants can be more likely to return if they know that they will be able to circulate between Senegal and Europe and to return in order to acquire other resources if needed.

In the same way as de Haas (2011) proposes migration be regarded as a function of individuals' aspirations and capabilities to migrate, it is equally possible to conceive return in terms of migrants' aspirations to and capabilities of return. The aspirations refer to the fact that migrants will return if they perceive good opportunities and good living conditions for them and their family in their origin country. However, migrants must also have the capability to return, which can be limited by factors such as insufficient earnings, or by migration policies. Migration policies implemented by destination countries may - directly or indirectly - prevent individuals from returning, which de Haas (2011) calls reverse substitution effects, ${ }^{1}$ as well as encourage or force them to return.

Some studies reveal that migration policies may play a crucial role for return migration, but this phenomenon has not been studied in depth due to the lack of individual data and migration policy data. Some hypotheses can however be drawn from the qualitative literature aiming at understanding return migration (Carling 2004; de Haas and Fokkema 2010), as well as the quantitative literature studying migration outflows (Czaika and de Haas 2014) and the return (Massey and Espinosa 1997; Massey et al. 2002; Reyes 2004; Flahaux 2013). I distinguish the role of three types of migration policy, each with a different objective, which is likely to affect return differently: (1) those that control the access of migrants to the territory of the destination country; (2) those regulating the stay of migrants in the destination country; and (3) those encouraging or forcing migrants to return.

\subsubsection{Policies to control access of migrants}

Some scholars have argued that restrictive migration policies aimed at controlling the access of migrants to the territory of the destination country discourage return migration and therefore push migrants into permanent settlement. Meaning if immigration restrictions decrease inflows, they may simultaneously also decrease return flows. This phenomenon has been described for 'guest worker' migration in European countries, where many temporary workers settled after the post-1973 recruitment ban (Böcker 1994; Castles and Miller 2009; Entzinger 1985). Similarly, qualitative research on Cape Verdean (Carling 2004), Moroccan

\footnotetext{
${ }^{1}$ Reverse flow substitution effects occur when immigration restrictions decrease return migration flows.
} 
(de Haas and Fokkema 2010) and Mexican (Cornelius 2001; Marcelli and Cornelius 2001; Massey and Espinosa 1997; Massey and Liang 1989; Massey et al. 2002; Reyes 2004) migration suggests that migrants may postpone or cancel their plans for return because of immigration policies becoming increasingly restrictive in destination countries.

A quantitative study on the intention and realisation of return to Senegal and DR Congo (Flahaux 2013) also suggests the unexpected effect of restrictive immigration policies. It shows that lower initial intentions to return and lower likelihood of return among migrants in Europe since 1990 (in comparison with those who migrated before 1990) may be related to the fact that it has become increasingly difficult to migrate to Europe. The rationale is that: given the restrictive immigration policies, migrants know it will be difficult to migrate again should they return and that their re-integration process would likely be problematic. In the same vein, findings also indicate that the Congolese and Senegalese who took complex routes to reach Europe are less likely to initially intend to return, and that the Congolese who took complex routes are less likely to realise that return (Flahaux 2015).

The study reveals that the harder it is to migrate to Europe, the less migrants intend to return and effectively do so (Flahaux 2013). The results of a macro-level quantitative analysis testing the effect of introducing visa requirements on bilateral migration flows between various countries seem to concur: the results suggest that travel visa requirements significantly decrease outflows (Czaika and de Haas 2014). Although the results of these studies suggest that there is an increase in the permanent settlement of migrants in developed countries because of an increasing difficulty in gaining access to the destination countries in Europe and America, the effect of migration policies in particular has not been studied.

\subsubsection{Policies to control the stay of migrants}

There is little evidence relating to the effect of migration policies aimed at regulating the stay of migrants in destination countries, but the effects can be considered as two-fold. The first effect is that where policies tend to reduce migrants' freedoms or opportunities in terms of working and living conditions, migrants may decide to leave and to return to their origin country since the situation in the destination country was not as they expected. For example, if migrants face obstacles attaining a work permit due to restrictive migration policies, they may decide to return.

The second effect, in line with the NELM theory, is that migrants return more slowly than expected or postpone their return due to the restrictions they experience in their attempts to integrate, because they need more time than anticipated to accumulate the resources required before returning (de Haas and Fokkema, 2011). In this regard, quantitative research shows that Senegalese who migrated to improve their living conditions were highly likely to intend to return when they arrived in Europe, but had a low propensity to do so in reality. This result is interpreted with reference to the difficulties migrants face integrating in Europe due to restrictive policies regulating their stay, for example access to the labour market. Therefore, they will in reality need more time than expected to save the necessary money to return (Flahaux 2013).

\subsubsection{Policies to encourage or force migrants to return}

When implementing policies encouraging or forcing migrants to return, policy makers expect these to have a positive impact on returns. Some studies, however, question the effectiveness of such policies. It appears that the impact of voluntary return programmes is limited because they are not attractive to migrants (Majidi 2010), and do not correspond to their needs 
(Linares 2009). These programmes, even when offering $€ 7,000$ to assist migrants' economic re-integration in their origin countries, seem derisory compared both to the sacrifices already made by migrants and their long-term projects. In other words, migrants know that any money received would be spent quickly and cannot compensate for the shortfall of the migration (Linares, 2009). Furthermore, this type of programme and deportation mainly targets undocumented migrants, who realise it will be difficult to migrate to Europe again if they return to their home countries. A quantitative survey showed that undocumented Congolese migrants are less likely to return than those who are documented (Flahaux 2013). This suggests that such migration policies have not always been effective.

Table 1 summarises the three main hypotheses derived from the literature (developed above) that will be tested in this paper.

- TABLE 1 ABOUT HERE -

\section{Methodology}

\subsection{Data requirements}

The objective of this study is to evaluate the influence of migration policy changes on return migration for Senegalese migrants to Europe. Such analysis requires both individual and contextual data. Individual data allows the study of the event of return for Senegalese who migrated to Europe. A transnational sample is needed that includes both Senegalese migrants in Europe, and migrants who returned to Senegal. Furthermore, a proper analysis of return migration requires time-varying data to understand the characteristics of migrants during each year of the migration, given that they may return in each year. Contextual data is needed to assess the migration policy changes by category of migrants, by destination country, and for each year. Indeed, migration policies evolve over time, vary from one destination country to another, and differ from one category of migrants to another. It is therefore important to use a dataset that accounts for these factors. Finally, data that assesses the situation in Senegal each year needs to be considered, as it may impact the decision to return.

\subsection{Data}

Few individual datasets present the required features to study the determinants of return migration. The biographic MAFE-Senegal survey (part of the Migration between Africa and Europe project $)^{2}$ is one of the few quantitative sources allowing such analyses, thanks to two main methodological characteristics. Firstly, it is a transnational dataset from surveys in both European countries - 603 Senegalese migrants were surveyed in Europe (about 200 in France, Italy and Spain) and in Senegal (1,067 interviewees in the Dakar region were surveyed, including non-migrants and returnees). ${ }^{3}$ Secondly, the data is time-varying by nature as it proceeds from individual life-histories as collected in biographical questionnaires. The data provides details of the respondents' lives, such as family composition, education and employment, housing, assets, their own migration trajectory as well as those of their personal network, etc. The data was collected annually, from the birth of individuals until the year of the survey (2008) (Beauchemin 2012). Detailed information on each stay of at least

\footnotetext{
${ }^{2}$ For information, see: http://mafeproject.site.ined.fr

${ }^{3}$ Surveys carried out in Europe contain a few return migrants (those who migrated again to Europe after a return to Senegal).
} 
one year in a destination country is available, including the migration duration expected at the time of arrival and the final destination expected, if any, which indicates the initial intention to return to the origin country or to settle abroad (Flahaux 2013).

For this paper we use data collected in Senegal, France, Italy and Spain, including both current and return migrants who have lived in these destination countries for at least one year. The Senegalese migrants considered in the sample were all born in Senegal, hold Senegalese citizenship and emigrated from Africa at age 18 or older and stayed abroad for at least one year. The sample includes 628 individuals, 675 migration episodes, 6892 personyears and 91 events of return, and is detailed in section 3. Return migration refers to a return to the country of origin with a long-term aim, and not to a short stay (visit). In this paper, return is defined as a stay in Senegal for at least one year, or less than one year where there is also the intention to settle.

The contextual information on migration policies comes from the DEMIG POLICY database (de Haas et al. 2014), a new database tracking major changes in migration policies of 45 countries - including France, Italy and Spain - constructed as part of the Determinants of International Migration (DEMIG) project. This database is underpinned by a systematic review of all reports of the OECD's Continuous Reporting System on Migration (SOPEMI reports, since 2006 commonly known as the OECD's International Migration Outlook) published annually between 1973 and 2013 - the national migration profiles compiled by the Migration Policy Institute - key academic articles on the countries' migration policy evolution, as well as national official documents and homepages, original legal texts and reports or overviews compiled by international organisations, think tanks and NGOs. In addition, every country dataset was reviewed by a national migration policy expert, which had the considerable advantage of enabling the inclusion of additional literature in the national language, as well as providing a quality check of the database.

The DEMIG POLICY database includes not only border control and entry policies, but also integration and exit policies that were implemented at the national level ${ }^{4}$. It distinguishes between policies targeting different categories of migrants (i.e. all migrants; all migrant workers; family members; international students; investors, entrepreneurs and business people; irregular migrants; low-skilled migrants; high-skilled migrants; refugees, asylum seekers and other vulnerable people). The objective of this database is to assess the effectiveness of migration policies in affecting the different targeted migrant categories. With this aim in mind, the DEMIG POLICY database evaluates any change in restrictiveness of each new policy measure introduced compared to the existing situation.

As such, for the policies regulating the access/stay of migrants to/in their origin country, it is assumed that a policy change represents an increase or decrease in restrictiveness when rights granted to the migrants of the targeted category decrease or increase respectively. Measures intending to restrict the rights of a migrant group are coded +1 (creating a more restrictive situation than before), while measures intending to increase the rights of a migrant group are coded -1 (creating a less restrictive situation than before). Regarding the policies regulating the return of migrants to their origin country, any policies aiming at encouraging or forcing migrants to return are coded -1 , as they are supposed to entice or force migrants to leave the destination country. DEMIG POLICY does not provide an assessment of the absolute level of restrictiveness of a specific policy within a country and

\footnotetext{
${ }^{4}$ DEMIG POLICY does not include integration policies implemented at a regional and urban level, although they may play a major role in the socio-economic integration of migrants at destination.
} 
over time, but it is an ordinal variable assessing the relative change in restrictiveness in a specific policy field.

This information does not allow a perfect comparison of the level of restrictiveness of migration policies for each category of migrants between countries, but is a good proxy to evaluate the number of policy measures implemented over time to control or ease migration for each category of migrants in each country. In addition to the DEMIG POLICY database, the DEMIG VISA database details the years travel visas were introduced for Senegalese to France, Italy and Spain after 1973. For the analysis of return, the data contained in DEMIG POLICY and DEMIG VISA were recoded to distinguish between policies aimed at (1) regulating the access of migrants to the destination country; (2) controlling the stay of migrants on their territory; and (3) encouraging or forcing migrants to return. Table 2 shows the policies considered for this purpose.

\section{- TABLE 2 ABOUT HERE -}

For this study, only policies implemented after 1900 are considered, and the restrictiveness of migration policies is assessed for five categories of migrants: irregular migrants, high-skilled migrants, low-skilled migrants, asylum seekers, and international students. The evolution of the migration policy changes for each of these categories of migrants is presented in the next section.

Annual GDP growth of Senegal data, computed from GDP estimates of the Maddison project $^{5}$, is used to measure the economic situation in the origin country over time. Data from 1950 to 2010 was available.

\subsection{Methods}

Discrete-time event history analysis was used to estimate the effects of different types of migration policies on the likelihood of return among Senegalese who migrated to France, Italy and Spain. This method divides time into discrete intervals of one year and estimates the probability of observing the event within each interval, given that it has not yet occurred (Allison 1982). In this case, as the event studied is the return to Senegal, every year spent by Senegalese in France, Italy and Spain is taken into account. Using the respondents' detailed migration histories, a time-varying dichotomous measure indicating whether a return event occurred in the current year is constructed. Individuals are considered likely to return at the time of their arrival in one of the three destination countries and are followed until they leave, until they acquire European citizenship or until the survey date, whichever occurs first. Their individual characteristics can vary over time.

As the variable on the level of restrictiveness can also differ by year, by category of migrants, and by destination country, the database from the DEMIG POLICY and VISA databases were merged with the sample of the MAFE-Senegal data on the basis of the year, destination country and migrant category. A migrant is considered an 'asylum seeker' when in a process of an asylum application; 'irregular' when undocumented (holding neither a residence permit nor European citizenship); 'student' when the main occupation is related to studies; 'high-skilled' when having studied more than three years of tertiary-level of education; and 'low-skilled' when not classed in one of the previous categories. ${ }^{6}$ Once a

\footnotetext{
${ }_{6}^{5}$ http://www.ggdc.net/maddison/maddison-project/home.htm

6 The category of family migrants is not included given the fact that this category is difficult to define and to implement in the analyses (Who are the individuals affected by migration policies related to families? The
} 
migrant acquires European citizenship they are excluded from the sample as they are no longer affected by migration policies.

As we have information on the characteristics of the migrants year-by-year, their classification can change over time. In some cases, a migrant could be considered in several categories in the same year, in which case I apply the most relevant category amongst those aimed at regulating the migrant's situation. For example, for a migrant who is classed as both high-skilled and irregular during the same year, the irregularity would take precedence because the migration policies targeting irregular migration will be more important for regulation. Likewise, if a student or a low-skilled migrant is irregular, it is his characteristic of irregularity that determines his legal status in the destination country. The following 'priority rule' was then implemented:

\section{Asylum seeker $>$ Irregular migrant $>$ Student $>$ High-skilled migrant $>$ Low-skilled migrant}

In sum, each migrant is affected each year spent in Europe, with three scores reflecting the restrictiveness of migration policies targeting each category in the destination country at that time. Table 3 shows an example of migrant $X$ who arrived in Spain in 2000 and is irregular during the four first years of migration. At that time, the level of restrictiveness of migration policies is quite high regarding the 'access' to Spain for irregular Senegalese migrants (level of '7'). In 2004, migrant X attained legal status and is then categorised a 'low-skilled' migrant, where the level of restrictiveness of migration policies regulating the 'access' to Spain is lower (level of ' 0 ' in 2004 and 2005). In 2006, Spain implements more liberal migration policies regarding the entry of low-skilled migrants, causing the level of restrictiveness to become ' -1 '. This example also shows that 'stay' and 'return' policies also vary over time.

\section{- TABLE 3 ABOUT HERE -}

A logistic regression is used to estimate the likelihoods of return, and results are presented as odds ratios. The variables related to the three types of migration policies are inserted separately in the model (a total of three models). These variables are categorical since they were recoded. Each modality of reference refers to negative and 0 scores, which corresponds to non-restrictive levels of restrictiveness in migration policies. Other modalities are compared with this modality of reference (scores from 1 to 4 ; and scores from a level of 5). Many variables are included in the model, in order to control for the characteristics of migrants (age, sex, educational level, family situation, material situation, professional situation, economic situation) and their migration experience (motive for migration, migration row, duration, visit(s), initial intention to return). I also control for the total number of policies implemented by a country to regulate migration across time, in order to take into consideration that a country can be more responsive to migration than others across time. Weights and replication (Jackknife) were used in order to take into account the sampling design and make the results more robust.

\section{Descriptive analysis}

\subsection{Restrictiveness of migration policies}

migrants or their families? Those having a family in Europe or in the origin country?). Moreover, given the categories have to be exclusive for the analyses, it was decided not to take them into account. Therefore, the policies targeting family migration are not taken into account. 
Table 4 shows that France, Italy and Spain have increasingly restricted access of Senegalese migrants to their territories over time, although to varying degrees across different categories of migrants. In all these countries, one can observe a tendency towards stricter policies to prevent the arrival of irregular migrants, particularly since 1990. Migration policies regulating the arrival of workers (both skilled and unskilled) have evolved differently: they have become relatively more restrictive since the 1970s, but were liberalised in Spain in the middle of the 1990s, reflecting the need for foreign labour in this country at that time.

\section{- TABLE 4 ABOUT HERE -}

Regarding the regulation of the stay of migrants in these three countries, Table 4 shows that there is considerable variation due to the different timing and extent of policies. France appears to have implemented increasingly restrictive policies over time, especially for irregular migrants after 1980, and workers, students and asylum seekers after 1990. In comparison, the policies implemented by Spain and Italy to regulate the stay of migrants have been less restrictive, especially for workers after the mid-1980s, and particularly in Spain. The level of restrictiveness of these policies has also decreased in Italy and Spain in the 1990 s for asylum seekers and students.

The variable reflecting policies of return shows that the three destination countries have increasingly tried since the 1990s to force or encourage irregular migrants to return, especially in France, but also in Italy, and to a lesser extent in Spain. Foreign workers in France have also been encouraged to return since the 1970s and since 2000 in Italy, while this has not been the case in Spain. Finally, policies of return have not specifically targeted students or asylum seekers.

\subsection{Migrant and return migrant characteristics}

As Figure 1 shows, more than half of Senegalese migrants are in the low-skilled workers category (i.e. have less than four years of tertiary-level education) the year of their arrival in France, Italy or Spain. While 28 per cent of migrants are irregular, 16 per cent are students, and high-skilled workers (i.e. have at least four years of tertiary-level education) and asylum seekers represent a minority of 1 per cent each.

Figure 1 also reveals that most return migrants were in the category of low-skilled workers before returning (67 per cent), followed by students (16 per cent). Irregular migrants represent 14 per cent of return migrants, but it does not mean that they have been encouraged or forced to return. Indeed, previous research indicates that irregular migrants return to Senegal spontaneously (Flahaux, 2013). Finally, there are very few migrants in the highskilled and asylum seekers categories.

\section{- FIGURE 1 ABOUT HERE -}

The detailed characteristics of migrants are reported in Table 5(a), and those of return migrants in table 5(b). These descriptive analyses suggest that Senegalese migrants have returned voluntarily and not under compulsion. Indeed, while only 3 per cent had more than three years of tertiary-level education at the time of their arrival, 10 per cent had achieved this by the time of return. Likewise, among migrants who returned, 63 per cent initially intended to return, compared to 43 per cent in the total sample of migrants the year of their arrival. In addition, while only 18 per cent of migrants had a property in Senegal at the time of their arrival in Europe, 40 per cent of those who returned have a property. Of return migrants 56 per cent have a family in Senegal, compared to 40 per cent in the total sample of 
migrants the year of their arrival. These results suggest that migrants return generally voluntarily to Senegal, after having acquired human and financial capital in Europe.

\section{- TABLE 5 ABOUT HERE -}

5 Results: The role of migration policies in return

\subsection{Determinants of return}

Table 6 shows the results of the 'control' variables of the first model. ${ }^{7}$ It appears that return is likely to occur for Senegalese migrants who have a strong attachment to Senegal and have acquired resources in Europe. Indeed, those who intended to return at the beginning of their migration are also more likely to return than those who intended to settle permanently in Europe. Moreover, those who have a family in Senegal are more likely to return than those living with their families in Europe. Furthermore, the duration of the migration, which might reflect the time needed to acquire resources, influences return: migrants who spent more than two years in Europe are more likely to return.

Migrants who have not returned for a short stay in Senegal during their migration are also more likely to return than those who have visited Senegal. This suggests that Senegalese who want to return prefer not to spend money visiting Senegal, instead preferring to save money for their project of reintegration after return; those visiting Senegal for short stays during their migration may have to postpone their return to absorb the associated costs. It also suggests that those who manage to keep in constant contact with Senegal via visits may delay their permanent return, finding in such a back and forth mobility strategy a good compromise between their stable situation in Europe and maintaining a status of prestige in Senegal. Results also highlight that Senegalese who are inactive or unemployed in Europe are more likely to return, which runs contrary to prevailing discourses about unemployed migrants staying in Europe to take advantage of social security benefits. Finally, Senegalese migrating for the second time to Europe are more likely to return. It shows that a first return may give rise to another migration with the intention to return permanently, probably because the new migration occurs to save enough money to return permanently to Senegal.

\section{- TABLE 6 ABOUT HERE -}

\subsection{Effect of migration policies}

Controlling for the above variables, Table 7 (1) shows that policies controlling the access of migrants to Europe have an effect on return migration to Senegal. When migrants face important restrictions in 'access' policies, they are less likely to return compared to during periods of lower restriction. Consistent with the initial hypothesis, it shows that restrictive migration policies in France, Italy and Spain aiming at limiting immigration discourage Senegalese from returning and push them instead into a longer settlement in the destination country. Indeed, when 'access' migration policies are very restrictive, thinking about the possibility of returning, migrants are aware that it will be difficult to migrate again to Europe if their re-integration process in Senegal is problematic. Therefore, they prefer not to take the risk of returning. Even if 'access' or 'entry' policies do not always correspond to 're-entry' policies, it is assumed to be a good proxy.

\footnotetext{
${ }^{7}$ These results are those of the model including the variable on policies controlling the access of migrants to Europe, but the two other models have given very similar results.
} 
Table 7 (2) also reveals that important restrictions in policies regulating the stay of migrants in Europe does not affect the return of migrants. Facing restrictive policies with respect to living in Europe, it is possible that some Senegalese migrants decide to return due to the difficulty of integrating in destination countries, while other migrants postpone their return because the context prevents them from accumulating the resources required for their return. In the end, a high level of restrictiveness of 'stay' policies may push some migrants to return and others to stay.

Table 7 (3) shows that, when measures are implemented to encourage or force migrants to return, they are not more likely to return than when these measures are inexistent or less developed. This result is in line with the initial hypothesis that questioned the effectiveness of such policies.

\section{- TABLE 7 ABOUT HERE -}

\section{Conclusion}

Migration policies in France, Italy and Spain have become more restrictive over time for Senegalese migrants, although this depends on the categories of migrants and on the destination countries. Based on how migration theories suggest that policy environments play a part in the return and the conceptualisation of return migration as a function of individual's aspirations and capabilities to return, this study aims to analyse the effect of the different types of migration policies on return among Senegalese who migrated to France, Italy and Spain.

The results show that migrants' aspirations in terms of what they consider as best for them and their family, determine their return. Indeed, those having the intention to return or having a family in Senegal are more likely to return. Migrants, however, need the capability of return. In line with the qualitative literature on Senegalese migration (Hernandez Carretero 2012, Sinatti 2011, Castagnone et al. 2005), the results show that migrants are more likely to return to Senegal when they have acquired resources to prepare their return. By preparing their return, they avoid the risk of failing to reintegrate (Flahaux, 2013). Moreover, the preoccupation of migrants is not only the return, but also the possibility of a further migration after the return. In this vein, the results reveal that Senegalese migrants are less likely to return when entry restrictions have become tighter. It suggests that policies aiming at limiting immigration discourage migrants to return and push them into a longer settlement in destination countries. This result reflects similar findings of previous studies about Mexican migrants in the United States (Massey and Espinosa 1997; Massey and Liang 1989; Massey et al. 2002; Reyes 2004).

Although some studies have suggested that restrictive migration policies have had a negative effect on return migration, it had not been empirically tested using both micro data on migrants' life histories and contextual data assessing the restrictiveness of migration policies for the different categories of migrants. In this regard this study is innovative, combining as it does data of the MAFE-Senegal biographic survey with that of the DEMIG policy and visa databases. By distinguishing the effect of different types of migration policies on return, this paper shows that policies aiming at controlling the stay and encouraging or forcing the return of migrants do not really affect return to Senegal, while restrictive policies regulating arrivals of migrants to France, Italy and Spain clearly reduce return. This result is crucial for theories and policies, as it highlights the fact that the possibility of circulating between country of origin and country of destination is essential for return migration. When 
conceptualising return migration, it is important to take into account the policy environment influencing migrant's aspirations. Policy makers in destination countries should take into consideration the finding that migrants regard the fact of return as risky, and that knowing that they will be able to circulate or to migrate again after their return will positively influence their decision to return. In other words, this research suggests that migration policies limiting circulation prevent return. 
References

Allison P.D., 1982. Discrete-Time Methods for the Analysis of Event Histories. Sociological

Methodology 13, p. 61-98.

Azoulay, M., Quiminal, C., 2002. Reconstruction des rapports de genre en situation migratoire. Femmes réveillées, hommes menacés en milieu soninké. VEI Enjeux, 128, 87101.

Beauchemin, C., 2012. Migrations between Africa and Europe: Rationale for a Survey Design. MAFE Methodological Note 5.

Barou, J., 2001. La famille à distance: nouvelles stratégies familiales chez les immigrés d'Afrique Sahélienne. Hommes et Migrations, 1232, 16-25.

Böcker, A.,1994. 'Chain migration over legally closed borders: settled migrants as bridgeheads and gatekeepers', Netherlands' Journal of Social Sciences 30(2), p. 87-106.

Bredeloup, S., 1995. Sénégalais en Côte d'Ivoire, Sénégalais de Côte d'Ivoire. Mondes en Développement 23 (91), 13-29.

Carling, J., 2004. Emigration, return and development in Cape Verde: the impact of closing borders. Popul. Space Place, 10 (2), 113-132.

Cassarino, J.-P., 2008. The Conditions of Modern Return Migrants - Editorial Introduction. International Journal on Multicultural Societies, 10 (2), 95-105.

Castagnone, E., Ciafaloni, F., Dinini, E., Guasco, D., Lanzardo, L., 2005. "Vai e vieni”. Esperienze di migrazione e lavoro di senegalesi tra Louga e Torino. FrancoAngeli Editore, Milano.

Castles, S. and M. J. Miller, 2009. The Age of Migration, Basingstoke and London: Macmillan. Cornelius, W.A., 2001. Death at the Border: Efficacy and Unintended Consequences of US Immigration Control Policy. Population and Development Review, 27 (4), p. 661-685.

Czaika, M. and de Haas, H., 2014. The effect of visa policies on international migration dynamics, DEMIG working paper, $26 \mathrm{p}$.

de Haas, H., 2005. International migration, remittances and development: myths and facts. Third World Quarterly, 26 (8), 1269-1284.

de Haas, H., 2011. The determinants of international migration. Conceptualizing policy, origin and destination effects. DEMIG project paper 2.

de Haas, H., Fokkema, T., 2010. Intra-Household Conflicts in Migration Decisionmaking: Return and Pendulum Migration in Morocco. Population and Development Review, 36 (2), 541-561.

de Haas, H., Fokkema, T., 2011. The Effects of Integration and Transnational Ties on International Return Migration Intention, Demographic Research, 25, 755-82.

de Haas, H., Natter, K., Vezzoli, S., 2014. Compiling and coding migration policies: Insights from the DEMIG POLICY database, International Migration Institute, DEMIG project paper 16, $43 \mathrm{p}$.

Entzinger, H., 1985. 'Return migration in Western Europe: current policy trends and their implications, in particular for the second generation', International Migration XXIII(2), p. 263-90. 
Flahaux, M.-L., 2013. Retourner au Sénégal et en RD Congo. Choix et contraintes au cœur des trajectoires de vie des migrants, Université catholique de Louvain, Presses universitaires de Louvain, Louvain-la-Neuve, 336 p.

Flahaux, M.-L., 2015. Return Migration to Senegal and the Democratic Republic of Congo: Intention and Realization, Population (English edition), 70 (1), 97-124.

Flahaux, M.-L., Kabbanji, L., 2013. L'encadrement des retours au Sénégal: logiques politiques et logiques de migrants. In C. Beauchemin, L. Kabbanji, B. Schoumaker, P. Sakho : Entre parcours de vie des migrants et attentes politiques, quel co-développement en Afrique subsaharienne? Armand Colin et INED, Paris.

Garip, F., 2012. Discovering Diverse Mechanisms of Migration: The Mexico-US Stream 1970-2000, Population and Development Review, 38 (3), 393-433.

Geddes, A., 2003. The politics of migration and immigration in Europe, Sage Publication, $221 \mathrm{p}$.

Guilmoto, C., 1998. Institutions and Migrations. Short-term Versus Long-term Moves in Rural West Africa. Population Studies, 52 (1), 85-103.

Hernandez Carretero, M., 2012. Morals and belonging in Senegalese transnational dynamics and trajectories. Communication présentée à l'atelier "Return migration and transnationalism: alternatives or complements" 4-5 septembre 2012, Peace Research Institute (PRIO), Oslo.

Jeffery, L., Murison, J., 2011. The temporal, social, spatial, and legal dimensions of return and onward migration. Population, Space and Place, 17 (2), 131-139.

Kaag, M., 2008. Mouride Transnational Livelihoods at the Margins of a European Society: The Case of Residence Prealpino, Brescia, Italy, Journal of Ethnic and Migration Studies, 34 (2), 271-285.

Lessault, D., Beauchemin, C., 2009. Ni invasion, ni exode. Regards statistiques sur les migrations d'Afrique subsaharienne. Revue européenne des migrations internationales, Nouvelles migrations chinoises en Afrique et en Amérique latine, 25 (1), 163-194.

Linares, A., 2009. Pourquoi les aides au retour et à la réinsertion de l'Etat français n'incitent pas les immigrés à rentrer dans leur pays d'origine? L'exemple des Maliens. Recueil Alexandries, Collections Synthèses.

Ma Mung, E., 1996. Mobilités et investissements des émigrés : Maroc, Tunisie, Turquie, Sénégal, L'Harmattan, Paris, 272 p.

Majidi, N., 2010. Strategies of migration and immigration: Afghan migrants and European state policies. Communication présentée à the 3rd Graduate Network Conference, Barcelona, 18-20 mars 2010.

Marcelli, E.A., Cornelius, W.A., 2001. The Changing Profile of Mexican Migrants to the United States: New Evidence from California and Mexico. Latin American Research Review, 36 (3), 105-131.

Massey, D.S., Espinosa, K.E., 1997. What's Driving Mexico-U.S. Migration? A Theoretical, Empirical, and Policy Analysis. American Journal of Sociology, 102 (4), 939-999.

Massey, D.S., Liang, Z., 1989. The long-term consequences of a temporary worker program: The US Bracero experience. Population Research and Policy Review, 8 (3), 199-226. 
Massey, D.S., Durand, J., Malone, N.J., 2002. Beyond smoke and mirrors: Mexican immigration in an era of economic integration. Russell Sage Foundation.

Massey, D.S., Pren K. A., 2012. Unintended Consequences of US Immigration Policy: Explaining the Post-1965 Surge from Latin America, Population and Development Review, 38 (1), 1-29.

Pison, G., Hill, K., Cohen, B., Foote, K., 1997. Les Changements démographiques au Sénégal, INED / PUF, 276 p.

Quiminal, C., 1991. Gens d'ici, gens d'ailleurs: migrations Soninké et transformations villageoises. Christian Bourgois, Paris.

Reyes, B., 2004a. Changes in Trip Duration for Mexican Immigrants to the United States. Population Research and Policy Review, 23 (3), 235-257.

Riccio, B., 2006. «Transmigrants » mais pas «nomades». Transnationalisme mouride en Italie, Cahiers d'études africaines, 181, 94-114.

Robin, N., 1996. Atlas des migrations ouest-africaines vers l'Europe, 1985-1993. IRD Editions.

Sinatti, G., à paraître. Return migration as a win-win-win scenario? Visions of Return among Senegalese Migrants, the State of Origin and Receiving Countries." Ethnic and Racial Studies.

Suarez Navaz, L., 1995. Les Sénégalais en Andalousie. Mondes en Développement 23 (91), $31-44$.

Tall, S.M., 2001. Les migrations internationales sénégalaises d'hier à demain. In M.C. Diop : La société sénégalaise entre le local et le global, Karthala, Paris, 549-578.

Timera, M., 1996. Les Soninké en France. Karthala, Paris, 250 p.

Todaro, M. P., 1969. A model of Labor Migration and Urban Unemployment in Less Developed Countries, American Economic Review, 59 (1), 138-148.

Vickstrom, E., 2014. Pathways into Irregular Status Among Senegalese Migrants in Europe, International Migration Review, 48 (4), 1062-1099. 


\section{Tables}

Table 1. Hypotheses about the influence of the three types of migration policies on return

\begin{tabular}{|l|l|}
\hline \multicolumn{1}{|c|}{ Policy type } & $\begin{array}{l}\text { Effect expected of migration policy changes } \\
\text { toward more restrictions on return migration }\end{array}$ \\
\hline $\begin{array}{l}\text { Policies to control access of migrants to their } \\
\text { territory }\end{array}$ & $\begin{array}{l}\text { Negative effect } \\
\text { (Restrictive policies likely to push migrants to } \\
\text { stay permanently abroad if they cannot circulate) }\end{array}$ \\
\hline $\begin{array}{l}\text { Policies to control the stay of migrants in their } \\
\text { territory }\end{array}$ & $\begin{array}{l}\text { Ambiguous effect } \\
\text { (Positive: migrants may choose to return if the } \\
\text { situation in the destination country is not as they } \\
\text { expected) } \\
\text { (Negative: migrants have to postpone or cancel } \\
\text { their return if their integration and ability to } \\
\text { acquire resources is difficult) }\end{array}$ \\
\hline $\begin{array}{l}\text { Policies encouraging or forcing migrants to } \\
\text { return }\end{array}$ & $\begin{array}{l}\text { No effect } \\
\text { (Policies likely to be ineffective) }\end{array}$ \\
\hline
\end{tabular}


Table 2. Policies regulating the entry, stay and return of migrants, and examples of specific migration policies used for the analysis of return

\section{Policies regulating the entry of Policies regulating the stay of migrants migrants to Europe}

Policies regulating the return of migrants to their origin country

\section{Travel visa}

e.g. Introduction of travel visa

$=+1$ for all migrants

Carrier liabilities

e.g. Increased penalties for

carriers of undocumented

migrants

$=+1$ for irregular migrants

Surveillance technologies

e.g. Creation of border

surveillance system

$=+1$ for irregular migrants

\section{Work permit}

e.g. Reduction of catalogue of occupations in short supply and of recruitment at source

$=+1$ for high-skilled and low-

skilled workers

\section{Quota/target}

e.g. Introduction of quota for non-EU workers in firms

$=+1$ for low-skilled workers

Recruitment/ assisted migration programme e.g. Labour agreement with Gambia, Guinea and Senegal $=-1$ for low-skilled workers and sanctions

\section{Expulsion}

e.g. Stronger link between asylum refusal and expulsion $=+1$ for asylum seekers

Readmission agreement e.g. Readmission agreement with Gambia, Guinea and Senegal $=+1$ for irregular migrants

Reintegration and return program

e.g. Voluntary return and resettlement aid launched $=+1$ for irregular migrants, unskilled and skilled workers

\section{Detention}

e.g. Detention in prison introduced for irregular migrants

$=+1$ for irregular migrants

Surveillance technology

e.g. Series of laws that reduce rights of foreigners and introduce more control

$=+1$ for all migrants

\section{Employer liabilities}

e.g. More control of employers and sanctions for irregular work

$=+1$ for irregular migrants

Entry visa/stay permit

e.g. Simplification of asylum procedures $=-1$ for asylum seekers

\section{Regularisation}

e.g. Regularisation programme

$=-1$ for irregular migrants

Free mobility rights

e.g. End of preferential treatment of free circulation for nationals of African

countries

$=+1$ for all migrants

Access to permanent residency

e.g. Grounds for withdrawing residency permit limited

$=-1$ for all migrants (excepted irregular)

Language, housing and cultural integration programmes

e.g. Widening of housing and funding for foreign workers beyond Algerians

$=-1$ for all (excepted irregular)

\section{Access to citizenship}

e.g. New requirements for naturalisation

$=+1$ for all migrants (excepted irregular)

Access to social benefit and socioeconomic rights

e.g. Access to social system granted to

legal and irregular migrants

$=-1$ for all migrants

Table 3. Migrant $X$ example

\begin{tabular}{|c|c|c|c|c|c|c|}
\hline Ident & $\begin{array}{l}\text { Destination } \\
\text { country }\end{array}$ & Year & Category & $\begin{array}{l}\text { (1) 'Access' } \\
\text { policies }\end{array}$ & $\begin{array}{c}\text { (2) 'Stay' } \\
\text { policies }\end{array}$ & $\begin{array}{l}\text { (3) 'Return' } \\
\text { policies }\end{array}$ \\
\hline
\end{tabular}




\begin{tabular}{lllllll}
\hline Migrant X & SPAIN & 2000 & Irregular & 7 & 0 & 0 \\
\hline Migrant X & SPAIN & 2001 & Irregular & 7 & 0 & 1 \\
\hline Migrant X & SPAIN & 2002 & Irregular & 7 & 0 & 1 \\
\hline Migrant X & SPAIN & 2003 & Irregular & 7 & 0 & -4 \\
\hline Migrant X & SPAIN & 2004 & Low-skilled & 0 & -5 & 0 \\
\hline Migrant X & SPAIN & 2005 & Low-skilled & 0 & -5 & 0 \\
\hline Migrant X & SPAIN & 2006 & Low-skilled & -1 & -5 & 0 \\
\hline Migrant X & SPAIN & 2007 & Low-skilled & -1 & -5 & 1 \\
\hline Migrant X & SPAIN & 2008 & Low-skilled & -1 & 0
\end{tabular}

Note. Scores reflect the level of restrictiveness for the three types of migration policies for each year 'migrant $\mathrm{X}^{\prime}$ lived in Europe (positive values $=$ more restrictive; negative values=less restrictive). 
Table 4. Migration policy changes targeting the different categories of migrants, by type of policies and country of destination. $x$ axis $=$ years $; y$ axis = number of changes toward more or less restriction or control (the higher the value is, the more 'restrictive' the migration policy changes have become).

\begin{tabular}{|c|c|c|c|c|c|c|}
\hline & Access & & Stay & & Return & \\
\hline France & (2) & $\begin{array}{l}\text { Irregular } \\
\text { High skilled } \\
\text { Low skilled } \\
-- \text { - Asylum seekers } \\
\square \text { Students }\end{array}$ & (10) & $\begin{array}{l}\text { — Irregular } \\
\text { High skilled } \\
\text { Low skilled } \\
- \text { - Asylum seekers } \\
\text { Students } \\
\end{array}$ & (20 & $\begin{array}{l}\text { Irregular } \\
\text { High skilled } \\
\text { Low skilled } \\
- \text { - Asylum seekers } \text { - Students }\end{array}$ \\
\hline Italy & \begin{tabular}{|r|r|}
20 \\
15 \\
10 \\
5 \\
0 \\
-5 \\
-10 \\
1960196519701975198019851990199520002005 \\
\end{tabular} & $\begin{array}{l}\text { Irregular } \\
\text { High skilled } \\
\text { Low skilled } \\
- \text { Asylum seekers }\end{array}$ & 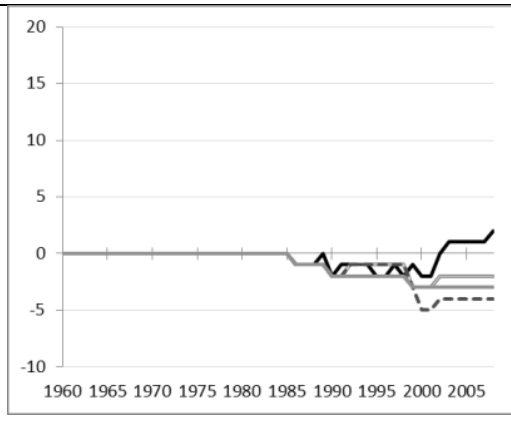 & $\begin{array}{l}\text { Irregular } \\
\text { High skilled } \\
\text { Low skilled } \\
-- \text { Asylum seekers } \\
\text { Students } \\
\end{array}$ & $\left.\begin{array}{|r|r|}20 \\
15 \\
10 \\
5 \\
0 \\
-5 \\
-10\end{array}\right]$ & $\begin{array}{l}\text { — Irregular } \\
\text { High skilled } \\
\text { Low skilled } \\
-- \text { - Asylum seekers } \\
\text { Students }\end{array}$ \\
\hline Spain & (10) & $\begin{array}{l}\text { — Irregular } \\
\text { High skilled } \\
\text { Lowskilled } \\
-- \text { Asylum seekers } \\
\square \text { Students } \\
\end{array}$ & (10) & $\begin{array}{l}\text { IIregular } \\
\text { High skilled } \\
\text { Low skilled } \\
\text { - } \text { - Asylum seekers } \\
\ldots \text { Students }\end{array}$ & {$\left[\begin{array}{c}20 \\
15 \\
10 \\
5 \\
-5 \\
-10\end{array}\right]$} & $\begin{array}{l}\text { — Irregular } \\
\text { High skilled } \\
\text { Low skilled } \\
\ldots \text { - Asylum seekers } \\
\text { Students }\end{array}$ \\
\hline
\end{tabular}


Table 5. Descriptive analysis of (a) migrant sample the year of their arrival in France, Italy or Spain, and (b) return migrant sample the year before their return to Senegal (results weighted)

\begin{tabular}{|c|c|c|c|}
\hline Variables & Modalities & (a) $\%$ & (b) $\%$ \\
\hline \multirow{3}{*}{ Age } & $18-29$ years & 65 & 30 \\
\hline & $30-44$ years & 32 & 59 \\
\hline & 45 years and more & 3 & 11 \\
\hline \multirow{2}{*}{ Sex } & Men & 70 & 66 \\
\hline & Women & 30 & 34 \\
\hline \multirow{2}{*}{ Education level } & No education, primary or secondary & 97 & 89 \\
\hline & Superior & 3 & 11 \\
\hline \multirow{5}{*}{ Motive for migration } & Family reason & 20 & 15 \\
\hline & To improve living conditions & 53 & 36 \\
\hline & Professional reason & 4 & 6 \\
\hline & To study & 14 & 29 \\
\hline & Other/missing & 9 & 13 \\
\hline \multirow{3}{*}{ Intention to return } & No & 47 & 32 \\
\hline & Yes & 43 & 63 \\
\hline & Do not know & 10 & 5 \\
\hline \multirow{2}{*}{ Migration row } & Not first migration & 10 & 27 \\
\hline & First migration & 90 & 73 \\
\hline \multirow{2}{*}{ Visit(s) } & No visit & 93 & 85 \\
\hline & At least one visit & 7 & 15 \\
\hline \multirow{5}{*}{ Family situation } & Family in Senegal & 40 & 56 \\
\hline & Family at destination & 10 & 4 \\
\hline & Single without children & 40 & 22 \\
\hline & Family at destination and origin & 6 & 7 \\
\hline & Family elsewhere & 4 & 10 \\
\hline \multirow{3}{*}{ Material situation } & Property in Senegal & 18 & 42 \\
\hline & Property at destination & 1 & 1 \\
\hline & No property & 81 & 56 \\
\hline \multirow{4}{*}{ Professional situation } & Active (and not underemployed/not overqualified) & 46 & 46 \\
\hline & Active (but underemployed/overqualified) & 17 & 14 \\
\hline & Inactive and unemployed & 20 & 24 \\
\hline & Student & 17 & 16 \\
\hline \multirow{3}{*}{ Economic situation } & Resources more than sufficient & 18 & 22 \\
\hline & Resources not more than sufficient & 81 & 72 \\
\hline & Missing & 1 & 6 \\
\hline $\mathbf{N}$ & & 675 & 91 \\
\hline
\end{tabular}


Table 6. Results of the logistic regression on return to Senegal from France, Spain and Italy: Effects of control variables (odds ratio)

\begin{tabular}{|c|c|c|}
\hline Variables & Modalities & Nets effects \\
\hline \multirow{3}{*}{ Age } & $18-29$ years (ref) & 1 \\
\hline & $30-44$ years & 1,18 \\
\hline & 45 years and more & 1,23 \\
\hline \multirow{2}{*}{ Sex } & Men (ref) & 1 \\
\hline & Women & 2,07 \\
\hline \multirow{2}{*}{ Education level } & No education, primary or secondary (ref) & 1 \\
\hline & Superior & 0,34 \\
\hline \multirow{4}{*}{ Motive for migration } & Family reason (ref) & 1 \\
\hline & To improve living conditions & 0,80 \\
\hline & Professional reason & 1,21 \\
\hline & To study & 6,02 \\
\hline \multirow{2}{*}{ Migration row } & Not first migration in Europe (ref) & 1 \\
\hline & First migration & $0,33^{* * *}$ \\
\hline \multirow{3}{*}{ Duration } & $1-2$ years (ref) & 1 \\
\hline & $3-5$ years & $2,40 * *$ \\
\hline & 6 years and more & $2,31 *$ \\
\hline \multirow{2}{*}{ Visit(s) } & No visit (ref) & 1 \\
\hline & At least one visit & $0,17^{* * * *}$ \\
\hline \multirow{2}{*}{ Initial intention to return } & Intention to settle permanently in Europe (ref) & 1 \\
\hline & Intention to return & $2,63 * *$ \\
\hline \multirow{4}{*}{ Family situation } & Family in Senegal & 1 \\
\hline & Family at destination & $0.06^{* * *}$ \\
\hline & Single without children & 0,65 \\
\hline & Family at destination and origin & 0,30 \\
\hline \multirow{3}{*}{ Material situation } & Property in Senegal (ref) & 1 \\
\hline & Property at destination & 0,17 \\
\hline & No property & 0,46 \\
\hline \multirow{4}{*}{ Professional situation } & Active (and not underemployed/not overqualified) (ref) & 1 \\
\hline & Active (but underemployed/overqualified) & 1,07 \\
\hline & Inactive and unemployed & $4,61 * *$ \\
\hline & Student & 0,50 \\
\hline \multirow{2}{*}{ Economic situation } & Resources more than sufficient (ref) & 1 \\
\hline & Resources not more than sufficient & 0,90 \\
\hline Annual GDP growth in Senegal & & 0,92 \\
\hline $\begin{array}{l}\text { Number of migration policies } \\
\text { implemented in the destination } \\
\text { country }\end{array}$ & & 0,99 \\
\hline Number of events & & 91 \\
\hline $\begin{array}{l}\text { Number of observations (person- } \\
\text { years) }\end{array}$ & & 6894 \\
\hline
\end{tabular}


Table 7. Results of the three logistic regressions on return to Senegal from France, Spain and Italy: effects of the policy variables (odds ratio)

(1)

\begin{tabular}{|l|l|l|}
\hline Variables & Modalities & Odd ratios \\
\hline \multirow{2}{*}{$\begin{array}{l}\text { Policies regulating the access of } \\
\text { migrants to Europe }\end{array}$} & Negative and 0 scores (non-restrictive) (ref) & 1 \\
\cline { 2 - 3 } & Scores of 1 to 4 (slightly restrictive) & 0,78 \\
\cline { 2 - 3 } & Scores of 5 and more (very restrictive) & $0,03^{* * *}$ \\
\hline $\mathbf{N}$ & 6892 (person-years) \\
\hline
\end{tabular}

$* * *: p<0.01 ; * *: p<0.05 ; *: p<0.10$

(2)

\begin{tabular}{|l|l|l|}
\hline Variables & Modalities & Odd ratios \\
\hline \multirow{2}{*}{$\begin{array}{l}\text { Policies regulating the stay of } \\
\text { migrants in Europe }\end{array}$} & Negative and 0 scores (non-restrictive) (ref) & 1 \\
\cline { 2 - 3 } & Scores of 1 to 4 (slightly restrictive) & 1,79 \\
\cline { 2 - 3 } & Scores of 5 and more (very restrictive) & 1,90 \\
\hline $\mathbf{N}$ & 6892 (person-years) \\
\hline
\end{tabular}

$* * *: \mathrm{p}<0.01 ; * *: \mathrm{p}<0.05 ; *: \mathrm{p}<0.10$

(3)

\begin{tabular}{|l|l|l|}
\hline Variables & Modalities & Odd ratios \\
\hline \multirow{3}{*}{$\begin{array}{l}\text { Policies regulating the return of } \\
\text { migrants from Europe }\end{array}$} & Negative and 0 scores (non-restrictive) (ref) & 1 \\
\cline { 2 - 3 } & Scores of 1 to 4 (slightly restrictive) & 0,97 \\
\cline { 2 - 3 } & Scores of 5 and more (very restrictive) & 1,51 \\
\hline N & 6892 (person-years) \\
\hline
\end{tabular}

$* * *: p<0.01 ; * *: p<0.05 ; *: p<0.10$ 